\title{
Postawy społeczności lokalnej wobec turystów i właścicieli gospodarstw agroturystycznych
}

Attitudes of the local community towards tourists and owners of agritourism farms

\section{Wprowadzenie}

Duży wpływ na rozwój turystyki na danym obszarze ma stosunek lokalnej społeczności do turystów. Tematykę tę opisywało wielu autorów w swoich pracach naukowych (Majdak, 2013; Williams \& Lawson, 2001; Andereck \& Vogt, 2000; Andereck, Valentine, Knopf \& Vogt, 2005; Eusébio \& Carneiro, 2012; Cañizares, Tabales \& Garcia, 2014). Potencjał społeczności lokalnej rozumiany jest „jako sprawność w określonej dziedzinie lub tkwiący w kimś (albo w czymś) zasób możliwości czy zdolności” (Marks-Krzyszkowska \& Jeziorska-Biel, 2017). Zdaniem Chaskina, Browna, Venkatesha i Vidala (2007) potencjał powstaje w wyniku zarówno formalnych, jak i nieformalnych interakcji między kapitałem ludzkim, społecznym i zasobami tej społeczności.

Można również zauważyć określone zmiany stosunku mieszkańców do turystów (tzw. indeks Doxeya (Doxey, 1976)). Pojawienie się negatywnych postaw mieszkańców wobec turystów jest rezultatem przekroczenia granic pojemności socjopsychologicznej, czyli zdolności akceptacji zachodzących zmian (Mika, 2007). Według Doxeya (1976) występują określone zmiany postaw mieszkańców do rozwoju turystyki w czterech kolejnych etapach: euforia, apatia, irytacja, konflikt. Inny podział typów stosunków pomiędzy społecznościami lokalnymi a turystami prezentuje Marie (1987), która wyróżnia:

- relacje konfliktowe,

- współistnienie w formie ugody (wzajemne ignorowanie lub pokojowa koegzystencja), 
- relacje synkretyczne - wzajemny wpływ, przy czym żadna ze stron nie traci swojej tożsamości,

- amnezja - w osłabionych społecznościach lokalnych obcy wpływ o dużym zasięgu (jak np. turystyka masowa) może wywołać poczucie agresji, na które społeczność lokalna zareaguje amnezją.

W opinii Kruczka (2018) nadmierna koncentracja ruchu turystycznego prowadzi do zatłoczenia atrakcyjnych miejsc, efektu przereklamowania i agresywnej komercjalizacji, co obniża poziom estetycznych doznań turystów i skutkuje degradacją naturalnych zasobów. Ponadto turystyka może mieć negatywny wpływ na społeczność lokalną, ponieważ wzrasta przestępczość, rozmiar społecznych patologii, następuje przejmowanie przez młodzież niewłaściwych wzorców zachowań zaczerpniętych z kultury masowej (Komorowska, 2003).

Postawy społeczności lokalnej mają również duży znaczenie dla rozwoju agroturystyki (Matlegiewicz, 2015; por. Głąbiński, 2018). Ta forma działalności pozarolniczej może mieć bezpośredni i pośredni wpływ na mieszkańców. Dzięki niej możliwe jest wspólne obcowanie mieszkańców miast i wsi. Ponadto buduje się w ludziach zadowolenie z przynależności do społeczności lokalnej, co sprzyja aktywizacji mieszkańców i zapobiega wyludnianiu się terenów wiejskich. Mieszkańcy mają również możliwość pozyskiwania pozarolniczych dochodów (Bakierska, 2010; por. Wiśniewska, 2009; por. Kuźniar, 2015).

\section{Istota turystyki wiejskiej i agroturystyki w literaturze przedmiotu}

Agroturystyka to jeden z rodzajów turystyki. Posiada ona określone cechy, odróżniające ją od pozostałych obszarów tego sektora usług (Niewiadomski, 2010). Pojęcie agroturystyki pojawiło się w literaturze polskiej i zagranicznej pod koniec XX wieku. Termin ten powstał z połączenia przedrostka ,agro-” ze słowem „turystyka”. „Agro” pochodzi od greckiego określenia agros, czyli „,rola”, i agronomos, odnoszącego się do zarządzania majątkiem rolnym. Turystyka to natomiast rodzaj czynnego wypoczynku poza miejscem zamieszkania, inspirowany m.in. potrzebami wypoczynkowymi i rekreacyjnymi, a także poznawczymi, kulturowymi, społecznymi itd., obejmujący wszelkie formy dobrowolnej zmiany miejsca pobytu (Sznajder \& Przezbórska, 2006).

W rozumieniu ogólnym, a także w literaturze przedmiotu, agroturystyka często utożsamiana jest $\mathrm{z}$ turystyką wiejską. Pojęcia te mają ze sobą wiele wspólnego, lecz nie są synonimiczne. W opracowaniach naukowych wiele miejsca poświęca 
się rozróżnieniu obu tych form turystyki, a ich autorzy zazwyczaj zwracają uwagę, że nie można ich traktować zamiennie. Termin „turystyka wiejska” obejmuje „całokształt gospodarki turystycznej odbywający się na terenach wiejskich" (Wiatrak, 1996). W tej definicji nacisk położony jest na ekonomiczny wymiar opisywanej formy rekreacji oraz na jej stronę podażową. Jako uzupełnienie można tu przywołać również wyjaśnienie pojęcia turystyki wiejskiej zaproponowane przez Sikorę, według którego „turystyka na terenach wiejskich obejmuje wszelką turystykę organizowaną na wsi”, a jej główny cel stanowi „przeciwstawienie atrakcji oraz warunków turystycznych środowiska wiejskiego miejskiemu" (Sikora, 1999).

Z przywołanych definicji wynika, że pojęcie turystyki wiejskiej jest szerokie i dotyczy wszystkich form turystyki oraz sposobów zagospodarowania turystycznego, które występują poza obszarami miasta. Obejmuje ona różne typy wypoczynku, krajoznawstwa oraz turystyki specjalistycznej, z którymi nierzadko wiąże się korzystanie z obiektów zlokalizowanych poza wsiami. W przypadku turystyki wiejskiej wypoczynku nie musi organizować rolnik lub inny stały mieszkaniec wsi. Agroturystyka natomiast jest jedną z form turystyki wiejskiej, ściśle łącząca się $z$ rolnictwem oraz funkcjonującym gospodarstwem rolnym. Dotyczy ona nie tylko usług turystycznych zlokalizowanych na obszarze wsi, ale także ściśle związanych z jej życiem społecznym, których podstawą są miejscowe zasoby przyrodnicze, materialne oraz ludzkie. Wymaga od turysty zaangażowania w określone prace polowe i włączenia się w rytm życia gospodarstwa (Machnik, 2008). Od turystyki wiejskiej odróżnia agroturystykę kilka podstawowych cech (Siekierski \& Popławski, 2009):

- agroturystyka ogranicza się ona do terenów typowo rolniczych, nie zaś do terenów wiejskich w znaczeniu administracyjnym;

- ważną rolę odgrywa w niej wykorzystanie budownictwa mieszkaniowego i gospodarczego ludności wiejskiej;

- bardzo istotne jest to, aby wypoczynek odbywał się w przyrodniczym otoczeniu gospodarstwa, a turyści mogli uczestniczyć w czynnościach gospodarskich lub przynajmniej je obserwować.

Definicję agroturystyki formułuje również Wiatrak (1996), wyjaśniając, że ten rodzaj turystyki „obejmuje organizowanie pobytu turystów przez rodzinę rolniczą we własnym gospodarstwie rolnym”. Natomiast według Sikory (2014) „agroturystyka jest działalnością rodziny rolniczej przy wykorzystaniu zasobów gospodarczych w celu przyjmowania gości i czerpania korzyści finansowych. Umożliwia ona turyście wypoczynek w naturalnym środowisku w celu poznawczym, zaspokojenia emocji czy odpoczynku".

Usługi agroturystyczne adresowane są przede wszystkim do turystów indywidualnych, rodzin czy innego rodzaju małych grup osób zainteresowanych 
czynnym wypoczynkiem i poszukujących spokoju, ciszy, a przede wszystkim bliskiego kontaktu z przyrodą, lubiących swobodnie i aktywnie spędzać wolny czas, jak również dążących do poznania nowych ludzi i miejscowych obyczajów oraz szukających kontaktu z folklorem. Usługi agroturystyczne nie wymagają rozbudowanej bazy noclegowej i gastronomicznej, przez co z powodzeniem mogą rozwijać się na podstawie zasobów mieszkaniowych już istniejących przy gospodarstwie rolnym. Do wypoczynku mogą służyć niewykorzystane obiekty inwentarskie, a także przestrzeń rekreacyjna w obrębie gospodarstwa. Istotne jest jednak to, by zaoferować turystom pożądany przez nich standard pobytu, zarówno w miejscu zakwaterowania, jak i w jego bezpośrednim otoczeniu (Siekierski \& Popławski, 2009).

\section{Cel, metody badawcze i charakterystyka badanej populacji}

Głównym celem opracowania było ukazanie postaw społeczności lokalnej wobec turystów i osób prowadzących działalność agroturystyczną w gminie Siemiatycze (województwo podlaskie). Do realizacji celu badań wykorzystano metodę sondażu diagnostycznego z techniką ankiety według standaryzowanego kwestionariusza. Badania zrealizowano w maju 2019 r., a kwestionariusz ankiety skierowany został do losowo wybranych mieszkańców gminy. W badaniach udział wzięło 52 respondentów. Charakterystykę społeczno-demograficzną badanych mieszkańców przedstawiono w tabeli 1.

Tabela 1. Charakterystyka społeczno-demograficzna badanych mieszkańców

\begin{tabular}{|l|c|c|}
\hline \multirow{2}{*}{ Wyszczególnienie } & \multicolumn{2}{|c|}{ Ogółem } \\
\cline { 2 - 3 } & $\mathrm{N}=52$ & $\%$ \\
\hline Płeć: & 28 & 53,8 \\
• kobieta & 24 & 46,2 \\
• mężczyzna & 4 & \\
\hline Wiek: & 4 & 7,7 \\
- poniżej 25 lat & 16 & 7,7 \\
- 25-34 lata & 10 & 30,8 \\
- 35-44 lata & 18 & 19,2 \\
- 45-60 lat & & 34,6 \\
\hline
\end{tabular}




\begin{tabular}{|c|c|c|}
\hline \multirow{2}{*}{ Wyszczególnienie } & \multicolumn{2}{|c|}{ Ogółem } \\
\hline & $\mathrm{N}=52$ & $\%$ \\
\hline \multicolumn{3}{|l|}{ Wykształcenie: } \\
\hline - podstawowe & 24 & 46,2 \\
\hline - zasadnicze zawodowe & 6 & 11,5 \\
\hline - średnie & 16 & 30,8 \\
\hline - wyższe & 6 & 11,5 \\
\hline \multicolumn{3}{|l|}{ Status zawodowy: } \\
\hline - pracownik umysłowy & 7 & 13,5 \\
\hline - pracownik fizyczny & 17 & 32,7 \\
\hline - emeryt/rencista & 22 & 42,3 \\
\hline - student & 2 & 3,8 \\
\hline - inne & 4 & 7,7 \\
\hline \multicolumn{3}{|l|}{$\begin{array}{l}\text { Średnia wysokość miesięcznego docho- } \\
\text { du przypadającego na jednego członka } \\
\text { rodziny (netto): }\end{array}$} \\
\hline • poniżej $1000 \mathrm{zl}$ & 18 & 34,6 \\
\hline • $1000-1500 \mathrm{zl}$ & 16 & 30,8 \\
\hline - powyżej $1500 \mathrm{zł}$ & 18 & 34,6 \\
\hline
\end{tabular}

Źródło: wyniki badań własnych.

Wśród badanych respondentów kobiety stanowiły blisko 54\%. Większość badanych osób znalazła się w przedziale wiekowym powyżej 35. roku życia $(84,6 \%)$. Prawie połowa respondentów $(42,3 \%)$ biorących udział w badaniach legitymowała się wykształceniem średnim i wyższym. Ważnym elementem charakterystyki społeczno-demograficznej był status zawodowy, ponieważ pracownicy umysłowi stanowili tylko 13,5\% badanej populacji. Większość badanych pochodziła z małych miejscowości i wsi (Romanówka, Ossolin, Baciki Średnie, Baciki Bliższe, Baciki Dalsze, Kajanka, Czartajew, Wólka Nadbużna). Co trzeci wskazał, że średnia wysokość miesięcznego dochodu przypadającego na jednego członka rodziny wynosiła powyżej $1500 \mathrm{zł}$.

Dodatkowo autor opracowania zastosował metodę CATI (wspomagany komputerowo wywiad telefoniczny) do zbadania opinii 11 właścicieli obiektów noclegowych prowadzących swoją działalność na terenie gminy Siemiatycze. 


\section{Wyniki badań}

W artykule szczególną uwagę zwraca się na postawy mieszkańców wobec rozwoju agroturystyki w gminie Siemiatycze. Z danych Podlaskiego Ośrodka Doradztwa Rolniczego w Szepietowie z 2019 r. w gminie Siemiatycze funkcjonowały 2 gospodarstwa agroturystyczne, natomiast w powiecie siemiatyckim - 22 obiekty (Podlaski Ośrodek Doradztwa Rolniczego w Szepietowie, 2019). Z kolei z danych Urzędu Gminy w Siemiatyczach z 2019 r. wynika, że działalność agroturystyczną na terenie gminy prowadziło 7 usługodawców (63 miejsca noclegowe) (Urząd Gminy w Siemiatyczach, 2019). W gminie Siemiatycze istnieje słabo rozwinięta baza noclegowa1. Problem ten częściowo rozwiązał rozwój prywatnych gospodarstw agroturystycznych, których liczba od kilku lat wzrasta (Boi, Romanówka, Ogrodniki, Słochy Annopolskie, Czartajew, Wólka Nadbużna). Najwięcej obiektów noclegowych znajduje się w miejscowości Wólka Nadbużna (leżącej przy rzece Bug).

Istotnym czynnikiem rozwoju agroturystyki jest częstotliwość kontaktów mieszkańców z turystami (dotyczy to nie tylko osób wybierających nocleg w gospodarstwach agroturystycznych, ale również turystów odwiedzających dane miejscowości bez zakwaterowania). Wyniki badań przeprowadzonych w gminie Siemiatycze porównano z innymi badaniami autorów krajowych i zagranicznych. Szczegółowe informacje na ten temat zaprezentowano w tabeli 2.

Tabela 2. Częstotliwość kontaktów mieszkańców z turystami [w \%]

\begin{tabular}{|l|c|c|c|c|}
\hline $\begin{array}{c}\text { Częstotliwość kontaktów } \\
\text { mieszkańców z turystami }\end{array}$ & $\begin{array}{c}2010^{*} \\
\mathrm{~N}=225\end{array}$ & $\begin{array}{c}2014^{* *} \\
\mathrm{~N}=151\end{array}$ & $\begin{array}{c}2015^{* * *} \\
\mathrm{~N}=308\end{array}$ & $\begin{array}{c}2019^{* * * *} \\
\mathrm{~N}=52\end{array}$ \\
\hline Ciągle & 13,3 & 9,3 & - & 1,9 \\
\hline Często & 16,9 & 21,9 & 25,5 & 13,5 \\
\hline Czasami & 25,8 & 16,6 & 48,0 & 23,1 \\
\hline Rzadko & 32,9 & 20,5 & 64,5 & 42,3 \\
\hline W ogóle & 11,1 & 11,3 & - & 19,2 \\
\hline
\end{tabular}

${ }^{\star}$ Na podstawie: Roman, 2011.

** Na podstawie: Roman \& Niedziółka, 2017.

${ }^{* * *}$ Na podstawie: Carneiro \& Eusébio, 2015. Badani mogli wskazać więcej niż jedną odpowiedź.

$* * * \star$ Wyniki badań własnych.

\footnotetext{
${ }^{1}$ Z informacji pozyskanych od właścicieli obiektów turystycznych wynika, że w $2019 \mathrm{r}$. w gminie Siemiatycze poza bazą agroturystyczną można było przenocować w pokojach do wynajęcia (5 miejsc noclegowych) w Krupicach, domkach letniskowych (35 miejsc noclegowych) w Wólce Nadbużnej, Pensjonacie SPA \& Wellness (160 miejsc noclegowych) w Wólce Nadbużnej oraz ośrodku wczasowym w Wólce Nadbużnej (150 miejsc noclegowych) (Urząd Gminy w Siemiatyczach, 2019).
} 
Z zaprezentowanych danych wynika, że kontakt mieszkańców z turystami miał charakter sporadyczny. Częstotliwość tych relacji w gminie Siemiatycze zestawiono z wiekiem badanych respondentów. Szczegółowe informacje zaprezentowano $\mathrm{w}$ tabeli 3 .

Tabela 3. Częstotliwość kontaktów mieszkańców gminy Siemiatycze z turystami w zależności od wieku respondentów [w \%]

\begin{tabular}{|l|c|c|c|c|c|c|c|}
\hline $\begin{array}{c}\text { Częstotliwość } \\
\text { kontaktów } \\
\text { mieszkańców } \\
\begin{array}{c}\text { z turystami w za- } \\
\text { leżności od wieku } \\
\text { respondentów }\end{array}\end{array}$ & \multicolumn{2}{|c|}{ Ogółem } & \multicolumn{5}{|c|}{ Wiek [w latach] } \\
\cline { 2 - 8 } & Odsetek & $\begin{array}{c}\text { Poniżej } \\
25\end{array}$ & $25-34$ & $35-44$ & $45-60$ & $\begin{array}{c}\text { Powyżej } \\
60\end{array}$ \\
\hline Ciągle & 1 & 1,9 & - & - & - & - & 100,0 \\
\hline Często & 7 & 13,5 & - & - & - & 28,6 & 71,4 \\
\hline Czasami & 12 & 23,1 & - & 16,7 & 33,3 & 16,7 & 33,3 \\
\hline Rzadko & 22 & 42,3 & 9,1 & 9,1 & 27,3 & 27,3 & 27,3 \\
\hline W ogóle & 10 & 19,2 & 20,0 & - & 60,0 & - & 20,0 \\
\hline
\end{tabular}

Źródło: wyniki badań własnych.

Osoby powyżej 45. roku życia miały częstsze kontakty z odwiedzającymi turystami. Mieszkańcy gminy Siemiatycze biorący udział w badaniach pozytywnie ustosunkowali się do turystów. Dane na ten temat zaprezentowano w tabeli 4.

Tabela 4. Stosunek mieszkańców do turystów [w \%]

\begin{tabular}{|c|c|c|c|c|c|}
\hline $\begin{array}{l}\text { Stosunek mieszkańców } \\
\text { do turystów }\end{array}$ & $\begin{array}{r}2010^{*} \\
\mathrm{~N}=225\end{array}$ & $\begin{array}{c}2010- \\
2011^{\text {}} \\
\mathrm{N}=614\end{array}$ & $\begin{array}{c}2010- \\
2012^{* * *} \\
\mathrm{~N}=900\end{array}$ & $\begin{array}{l}2014^{* * * *} \\
\mathrm{~N}=151\end{array}$ & $\begin{array}{c}2019^{* * * * *} \\
\mathrm{~N}=52\end{array}$ \\
\hline Pozytywny & 50,7 & 72,2 & 39,0 & 72,8 & 81,2 \\
\hline Obojętny & 40,8 & - & 54,0 & 26,5 & 15,9 \\
\hline Negatywny & 8,5 & 18,8 & 7,0 & 0,7 & 2,9 \\
\hline
\end{tabular}

* Na podstawie: Roman, 2011. Opracowanie dotyczy następujących gmin wiejskich województwa podlaskiego: Białowieża, Giby, Grajewo, Gródek, Janów, Jaświły, Jeleniewo, Mielnik, Narewka, Nowinka, Płaska, Sokoły, Trzcianne, Turośl, Wizna.

** Na podstawie: Mika, 2013. Opracowanie dotyczy następujących gmin województwa śląskiego: miejskich Ustroń, Wisła, wiejskich - Brenna, Istebna.

*** Na podstawie: Kuźniar, 2015. Opracowanie dotyczy wybranych gmin wiejskich województwa podkarpackiego.

**** Na podstawie: Roman \& Niedziółka, 2017. Opracowanie dotyczy następujących gmin wiejskich województwa podlaskiego: Giby, Krasnopol, Nowinka, Płaska, Sejny, Suchowola, Suwałki i Jeleniewo. ***** Wyniki badań własnych.

Z większości zaprezentowanych wyników badań różnych autorów wynika, że stosunek mieszkańców do przyjeżdzających turystów był pozytywny. Ważnym 
zagadnieniem są relacje mieszkańców gmin z osobami prowadzącymi gospodarstwa agroturystyczne. Szczegółowe dane zaprezentowano w tabeli 5.

Tabela 5. Stosunek mieszkańców gmin do osób prowadzących działalność agroturystyczną [w \%]

\begin{tabular}{|l|c|c|}
\hline \multicolumn{1}{|c|}{$\begin{array}{c}\text { Stosunek mieszkańców gmin do osób prowadzących } \\
\text { działalność agroturystyczną }\end{array}$} & $\begin{array}{c}2010^{*} \\
\mathrm{~N}=225\end{array}$ & $\begin{array}{c}2019^{* *} \\
\mathrm{~N}=52\end{array}$ \\
\hline Przyglądam się z zaciekawieniem & 30,7 & 43,8 \\
\hline Aprobuję & 40,4 & 38,8 \\
\hline Obojętny/neutralny & 24,9 & 13,5 \\
\hline Zazdroszczę & 1,3 & 1,9 \\
\hline Negatywny & 1,8 & 1,9 \\
\hline
\end{tabular}

* Na podstawie: Roman, 2014.

** Wyniki badań własnych.

Z zaprezentowanych wyników badań wynika, że mieszkańcy gmin aprobowali, jak również przyglądali się z zaciekawieniem działaniom podejmowanym przez usługodawców gospodarstw agroturystycznych. Najmniejsza część respondentów była negatywnie nastawiona do osób prowadzących taką działalność. Może to być spowodowane kreowaniem złych wzorców zachowań we wsiach przez osoby przejeżdżające do gospodarstw agroturystycznych.

Agroturystyka może przynieść korzyści społecznościom lokalnym. Z przeprowadzonych badań w gminie Siemiatycze wynika, że $80,8 \%$ badanych osób nie odnosiło korzyści materialnych związanych z pobytem turystów. Pozostałe osoby sprzedawały produkty pochodzące $\mathrm{z}$ własnego gospodarstwa domowego (np. jaja - 9 osób, mleko - 4 osoby, sery - 3 osoby, grzyby - 2 osoby).

Agroturystyka może mieć również negatywny wpływ, np. degradacja, zarówno środowiska naturalnego (szerzej na ten temat: Batyk, 2011; Mocior, 2014) oraz tego stworzonego pracą ludzką, jak i przejmowanie przez ludzi negatywnych wzorców zachowań oraz przeludnienie, hałas, a także wzrost cen.

\section{Wnioski}

Badania wykazały różnorodność postaw mieszkańców badanej gminy w stosunku do turystów i osób prowadzących gospodarstwa agroturystyczne:

- osoby biorące udział $\mathrm{w}$ badaniach pozytywnie ustosunkowały się do turystów i właścicieli gospodarstw agroturystycznych; 
- osoby powyżej 45. roku życia miały częstsze kontakty z odwiedzającymi gminę turystami;

- tylko 2,9\% respondentów nastawiona była negatywnie do przyjeżdzających osób. Negatywny odbiór turystów przez mieszkańców był spowodowany kreowaniem złych wzorców zachowań we wsiach.

Podsumowując, rozwój agroturystyki na obszarze gminy Siemiatycze może przyczynić się do zwiększenia sprzedaży produktów pochodzących z gospodarstwa rolnego, wzrostu dochodów ludności i podniesienia poziomu życia. Może zatem dostarczyć wielu korzyści społecznościom wiejskim, choć zarazem - niewłaściwe ukierunkowana i pozostawiona bez kontroli - może ujemnie wpłynąć na obszary wiejskie. Jednym z zagrożeń jest wysoki poziom zanieczyszczeń, będący możliwym wynikiem zwiększonego zaśmiecania oraz zagęszczenia ruchu.

Istotnym czynnikiem rozwoju agroturystyki są pozytywne relacje między społecznością lokalną a turystami. Ponadto, aby nastąpił znaczący był wzrost zainteresowania turystów tą formą wypoczynku, należy wprowadzać innowacje. Dzięki temu turyści mogą otrzymać satysfakcję z oferowanych usług oraz zaspokajać swoje potrzeby. W zależności od miejsca i możliwości w grę mogą wchodzić rozwiązania najprostsze, takie jak np. wprowadzenie indywidualnie dostosowanego jadłospisu czy podnoszenie standardu, jak również bardziej skomplikowane działania: współpraca transgraniczna czy gospodarstwa opiekuńcze (np. właściciele gospodarstwa zajmujący się osobami z chorobami kręgosłupa). Warto zdobywać nowe doświadczenia od właścicieli gospodarstw agroturystycznych za granicą, aby nadążać za oczekiwaniami klienta, które stale rosną, oraz móc wykorzystać rozwiązania zdobywające dopiero popularność, ale mogące dawać większy przychód. Ważne jest, aby przy wprowadzaniu zmian nie zatracić walorów kulturowych i naturalnych. Innowacyjność polega na wprowadzeniu czegoś niezwykłego, czego do tej pory turyści nie widzieli, co spowoduje zainteresowanie, chęć powrotu w dane miejsce, a także podzielenie się ze znajomymi pozytywną opinią. Sposobów na przyciągnięcie turystów jest wiele, ale najważniejszym jest pomysł i chęć realizacji nowych przedsięwzięć, pomimo praktycznych barier, które niekiedy mogą stawać na przeszkodzie. Warto również podkreślić, że nowatorskie pomysły mogą mieć wpływ na tworzenie nowych miejsc pracy. Społeczność na terenach wiejskich zazwyczaj zajmuje się uprawą roli, a tworzenie gospodarstw to możliwość na dodatkowy dochód przy tworzeniu niebanalnych i nietypowych atrakcji.

Zaprezentowane w opracowaniu badania miały charakter pilotażowy. Przedstawione zagadnienia mają istotny wpływ na ukazanie wybranych czynników dynamizujących rozwój agroturystyki. Na obszarach wiejskich występują dy- 
namiczne zmiany, dlatego też warto w przyszłości przeprowadzić pogłębione badania dotyczące postaw społeczności lokalnej wobec rozwoju agroturystyki na większej próbie badawczej w Polsce i w wybranych krajach europejskich.

\section{Bibliografia}

Andereck, K. L., \& Vogt, C. A. (2000). The Relationship between Residents' Attitudes toward Tourism and Tourism Development Options. Journal of Travel Research, 39, 27-36. https://doi.org/10.1177\%2F004728750003900104

Andereck, K. L., Valentine, K. M., Knopf, R. C., \& Vogt, C. A. (2005). Residents' perceptions of community tourism impacts. Annals of Tourism Research, 32(4), 1056-1076. https://doi.org/10.1016/j.annals.2005.03.001

Bakierska, A. (2010). Agroturystyka jako sposób aktywizacji społeczności lokalnej. Pobrano z: http://www.pokl.up.podlasie.pl/uploads/upload/podstrona_pokl/agroturystyka/7-9\%20Lipowy\%20Most/Agroturystyak_jako_sposob_aktywizacji_lokalnej_spolecznosci.pdf (06.07.2019).

Batyk, I. M. (2011). Wpływ działalności turystycznej na zrównoważony rozwój obszarów wiejskich województwa warmińsko-mazurskiego. Infrastruktura i Ekologia Terenów Wiejskich, 1, 51-60.

Cañizares, S. M. S., Tabales, J. M. N., \& Garcia, F. J. F. (2014). Local residents' attitudes towards the impact of tourism development in Cape Verde. Tourism \& Management Studies, 10(1), 87-96.

Carneiro, M. J. A., \& Eusébio, C. A. (2015). Host-tourist interaction and impact of tourism on residents' Quality of Life. Tourism \& Management Studies, 11(1), 25-34.

Chaskin, R. J., Brown, P., Venkatesh, S., \& Vidal, A. (2007). Budowanie potencjału społeczności lokalnej. W: T. Kazimierczak (red.), Zmiana w społeczności lokalnej. Szkice o kapitale społecznym $w$ praktyce społecznej i nie tylko (s. 37-71). Warszawa: Wydawnictwo Instytutu Spraw Publicznych.

Doxey, G. V. (1976). When enough's enough: the natives are restlessin Old Niagara. Heritage Canada, 2(2), 26-27.

Eusébio, C. A., \& Carneiro, M. J. A. (2012). Determinants of tourist-host interactions: an analysis of the university student market. Journal of Quality Assurance in Hospitality \& Tourism, 13(2), 123-151. https://doi.org/10.1080/1528008X.2012.645201

Głąbiński, Z. (2018). Stosunek mieszkańców powiatu gryfińskiego do rozwoju turystyki w świetle badań jakościowych. Przeglad Zachodniopomorski, 33(1), 191-220. https://doi.org/10.18276/pz.2018.1-08

Komorowska, K. A. (2003). Turystyka a społeczności lokalne - przykład tatrzański. Studia Regionalne i Lokalne, 3(13), 79-96. 
Kruczek, Z. (2018). Turyści vs. mieszkańcy. Wpływ nadmiernej frekwencji turystów na proces gentryfikacji miast historycznych na przykładzie Krakowa. Turystyka Kulturowa, 3, 29-41.

Kuźniar, W. (2015). Postawy lokalnej społeczności wobec rozwoju turystyki wiejskiej i ich konsekwencje dla obszaru recepcji. Nierówności Społeczne a Wzrost Gospodarczy, 42(2), 296-305.

Machnik, A. (2008). Rozwój działalności agroturystycznej w gospodarstwach rolnych. Poznań: Dom Wydawniczy Harasimowicz.

Majdak, P. (2013). Społeczności lokalne wobec turystyki. Postawy - oczekiwania - konflikty w świetle koncepcji rozwoju zrównoważonego. Turystyka i Rekreacja, 10(1), 65-71.

Marie, M. (1987). Społeczności lokalne i turystyka: kierunki badań. Problemy Turystyki, 2(36), 17-22.

Marks-Krzyszkowska, M., \& Jeziorska-Biel, P. (2017). Potencjał społeczności lokalnych w rozwoju turystyki Żuławek. Studia Obszarów Wiejskich, 46, 7-25. https://doi. org/10.7163/SOW.46.1

Matlegiewicz, M. (2015). Agroturystyka - pozarolniczy biznes polskiej wsi. Ekonomia i Środowisko, 4(55), 221-234.

Mika, M. (2007). Przemiany pod wpływem turystyki na obszarach recepcji turystycznej. W: W. Kurek (red.), Turystyka (s. 433-436). Warszawa: PWN.

Mika, M. (2013). Postawy społeczności lokalnych wobec turystów i rozwoju turystyki przykład gmin Beskidu Śląskiego. Prace Geograficzne, 134, 83-100.

Mocior, E. (2014). Rola agroturystyki w zrównoważonym rozwoju obszarów wiejskich powiatu włodawskiego. Problemy Ekologii Krajobrazu, XXXVII, 103-111.

Niewiadomski, K. (2010). Agroturystyka a turystyka - ze szczególnym uwzględnieniem relacji do przestrzeni wiejskiej na przykładzie obszaru województwa podlaskiego. Zeszyty Naukowe Polityki Europejskie, Finanse i Marketing, 3, 456-467.

Podlaski Ośrodek Doradztwa Rolniczego w Szepietowie. (2019). Powiat siemiatycki. Pobrano z: http://odr.pl/agroturystyka/kwatery-agroturystyczne/powiat-siemiatycki-91825369/ (20.05.2019).

Roman, M. (2011). Postawy społeczności lokalnej wobec rozwoju agroturystyki w gminach wiejskich województwa podlaskiego. W: I. Sikorska-Wolak (red.), Społeczno-kulturowe uwarunkowania rozwoju turystyki na obszarach wiejskich (s. 19-37). Warszawa: Wydawnictwo SGGW.

Roman, M. (2014). Ekonomiczno-społeczne uwarunkowania rozwoju agroturystyki w gminach wiejskich województwa podlaskiego. Golądkowo: Wydawnictwo Zespołu Szkół Centrum Kształcenia Rolniczego im. Jadwigi Dziubińskiej w Golądkowie. 
Roman, M., \& Niedziółka, A. (2017). Agroturystyka jako forma przedsiębiorczości na obszarach wiejskich. Warszawa: Wydawnictwo SGGW.

Siekierski, J., \& Popławski, Ł. (2009). Usługi turystyczne jako forma przedsiębiorczości na obszarach wiejskich. Zeszyty Naukowe Małopolskiej Wyższej Szkoły Ekonomicznej $w$ Tarnowie, 3, 153-164.

Sikora, J. (1999). Organizacja ruchu turystycznego na wsi. Warszawa: WSiP.

Sikora, J. (2014). Turystyka wiejska, w tym agroturystyka, w kontekście perspektyw rozwoju wsi i rolnictwa w Polsce. Analiza wyników badań empirycznych. Ekonomiczne Problemy Turystyki, 3, 113-126.

Sznajder, M., \& Przezbórska, L. (2006). Agroturystyka. Warszawa: PWE.

Urząd Gminy w Siemiatyczach. (2019). Noclegi. Pobrano z: http://gminasiemiatycze.pl/ turystyka/noclegi.html (20.05.2019).

Wiatrak, A. P. (1996). Wpływ agroturystyki na zagospodarowanie obszarów wiejskich. Zagadnienia Ekonomiki Rolnej, 1, 34-46.

Williams, J., \& Lawson, R. (2001). Community Issues and Resident Opinions of Tourism. Annals of Tourism Research, 28(2), 269-290. https://doi.org/10.1016/S0160-7383(00)00030-X

Wiśniewska, A. (2009). Gospodarczy aspekt rozwoju agroturystyki w nadmorskich gminach Ustka i Choczewo. Stupskie Prace Geograficzne, 6, 117-128.

\section{Streszczenie}

Celem opracowania było ukazanie postaw społeczności lokalnej wobec turystów i osób prowadzących działalność agroturystyczną w gminie Siemiatycze (województwo podlaskie). Do jego realizacji wykorzystano metodę sondażu diagnostycznego z techniką ankiety według standaryzowanego kwestionariusza. Badania zrealizowano w maju 2019 roku, a kwestionariusz ankiety skierowany został do wybranych losowo mieszkańców gminy. W badaniach udział wzięło 52 respondentów. Dodatkowo autor opracowania zastosował metodę CATI (wspomagany komputerowo wywiad telefoniczny) z 11 właścicielami obiektów noclegowych, prowadzącymi swoją działalność na terenie gminy Siemiatycze. Badania wykazały różnorodność postaw mieszkańców badanej gminy w stosunku do turystów i osób prowadzących gospodarstwa agroturystyczne. Respondenci pozytywnie ustosunkowali się do turystów i właścicieli gospodarstw agroturystycznych. Osoby powyżej 45. roku życia miały częstsze kontakty z odwiedzającymi turystami. Tylko 2,9\% respondentów nastawiona była negatywnie do przyjeżdzających osób. Negatywny odbiór turystów przez mieszkańców był spowodowany kreowaniem złych wzorców zachowań we wsiach.

SŁOWA KLUCZOWE: agroturystyka, postawy, społeczność lokalna, region, gmina Siemiatycze, województwo podlaskie 


\section{Summary}

The main purpose of the study was to show the attitudes of the local community towards tourists and people running agritourism activities in the municipality of Siemiatycze (Podlaskie Voivodeship). To achieve the objective of the study, the diagnostic survey method was used together with the survey technique according to a standardized questionnaire. The research was carried out in May 2019, and the questionnaire was addressed to randomly selected residents of the municipality. 52 respondents took part in the research. In addition, the author of the study applied the CATI (computer-assisted telephone interview) method with respect to 11 owners of accommodation facilities operating in the Siemiatycze municipality. Research has shown a variety of the inhabitants' attitudes in the examined municipality towards tourists and people running agritourism farms. The inhabitants of the municipality who took part in the survey positively responded to tourists and agritourism farm owners. People over 45 years old had more frequent contact with visiting tourists. Only $2.9 \%$ of respondents were negative about incoming people. Negative reception of visitors by residents was caused by tourists creating bad behaviour patterns in the villages. The development of agritourism in the municipality may contribute to an increase in the demand for products manufactured in an agricultural enterprise, an increase in the income of the population and the improvement of the living standard. Agritourism can provide rural communities with many benefits, however, improper orientation and leaving it out of control can also negatively affect rural areas. One of the risks is the high level of pollution which may be the result of increased littering and the increase in transport volume.

KEYWORDS: agritourism, attitudes, local community, region, Siemiatycze municipality, Podlaskie voivodship 